\title{
GRUNNSKÓLASTJÓRAR Á ÖNDVERĐRI 21. ÖLD: HLUTVERK OG GILDI
}

Nútímakenningar um skólastjórnun beina kastljósinu m.a. að sýn skólastjóra á hlutverk sitt, peim gildum sem hafa áhrifá starfshætti peirra (Begley, 2004; Branson, 2005) og hvernig peir forgangsrađa verkefnum sínum. Á síðasta aldarfjórđungi hafa höfundar pessarar greinar rannsakađ viðhorf skólastjóra í grunnskólum međ spurningalistakönnunum, p.e. 1991, 2001 og 2006 (Börkur Hansen, Ólafur H. Jóhannsson og Steinunn Helga Lárusdóttir, 2008). Hér er greint frá rannsókn á störfum skólastjóra sem gerð var 2017. Sjónum er beint að peim gildum sem peir segjast leggja mesta áherslu á og hvernig peir forgangsrađa helstu verkefnum sínum. Gögnum var safnađ međ spurningalista sem sendur var til allra skólastjóra í grunnskólum landsins vorið 2017. Dregin er upp mynd af aðstæðum í skólunum, p.e. skólagerð, skólastærð og kennslufyrirkomulagi, og afstađa skólastjóra til mikilvægra gilda sem tengjast skólastarfi er könnuð. Einnig var athugað hvernig peir forgangsrađa verkefnum, svo sem vinnu við námskrárgerđ, samskiptum við starfsfólk, nemendur o.fl. sem tengist störfum peirra. Niðurstöđur benda til pess að nokkurs ósamræmis gæti milli yfirlýstra gilda skólastjóra og raunverulegra. Greininni lýkur með samanburđi við fyrri rannsóknir höfunda á forgangsröđun viðfangsefna skólastjóra og umræđum um gildi niðurstaðnanna.

Efnisorð: skólastjórar, gildi, forgangsröđun verkefna, forysta

\section{INNGANGUR}

Á undanförnum áratugum hefur áhugi á getu skóla til ađ sinna hlutverki sínu farið vaxandi. Ein birtingarmynd pessa áhuga er rannsóknir á áhrifum skólastjórans á skólastarf, einkum forystu hans á sviđi náms og kennslu og áhrifum hennar á námsárangur (Börkur Hansen og Steinunn H. Lárusdóttir, 2014; Hallinger, 2009; Leithwood, Harris og Hopkins, 2008; Leithwood og Mascall, 2008; Sergiovanni, 2009).

Samkvæmt lögum er pađ hlutverk skólastjóra sem faglegs leiđtoga ađ móta og leiđa skólastarfið (lög um grunnskóla, nr. 91/2008) og í Ađalnámskrá grunnskóla (Mennta- og menningarmálaráđuneyti, 2012) segir ađ skólastarf skuli vera í sífelldri mótun í samræmi við nýja pekkingu og breyttar pjóđfélagsađstæđur. Skólar eru margbrotnar stofnanir og 
verkefnin sem parf að sinna eru mörg. Hlutverk skólastjóra er bví fjölpætt. Nútímakenningar um skólastjórnun beina kastljósinu ađ sýn skólastjóra á hlutverk sitt og pví hvernig tengslum peirra við samstarfsfólk sitt er háttað. pá er átt við hvort stjórnendur séu framsæknir og eigi virkt samstarf við kennara um að próa skólastarf og kennsluhætti (Harris, 2008; Hoy og Miskel, 2008; Kaplan og Owings, 2015; Louis, Leithwood, Wahlstrom og Anderson, 2010; Robinson, 2011; Sergiovanni, 2009). Í rannsóknarverkefninu Starfshættir í grunnskólum viđ upphaf 21. aldar kemur fram að sýn skólastjóra á hlutverk sitt á sviði náms og kennslu er mismunandi. Niðurstöđur benda einnig til pess ađ skólastjórar veiti kennurum litla beina leiðsögn varđandi kennslu en hafi aftur á móti talsverđ óbein áhrif með peim aðstæðum eða umhverfi til starfspróunar sem peir skapa kennurum (Börkur Hansen og Steinunn Helga Lárusdóttir, 2014).

Rannsóknir Barkar Hansen, Ólafs H. Jóhannssonar og Steinunnar Helgu Lárusdóttur (2008) sem gerđar voru árin 1991, 2001 og 2006 veita annars vegar innsýn í pađ hvernig skólastjórar í grunnskólum verja tíma sínum og hins vegar hvernig peir vildu verja honum. Öll árin segjast peir verja mestum tíma í páttinn stjórnun og umsýsla, p. e. viðfangsefni sem snúa ađ fjármálum, rekstri og skrifstofuhaldi. Öll árin er á hinn bóginn námskrárvinna í fyrsta sæti hjá skólastjórum yfir pađ sem peir helst vildu verja tíma sínum í, p.e. viđfangsefni tengd próun námskrár, kennsluháttum, kennsluskipulagi, námsefni og viđlíka verkpáttum. Petta má líta á sem vísbendingu um ađ fagleg málefni séu ekki í forgrunni í viðfangsefnum skólastjóra í peim mæli sem peir helst kysu.

Nú er um aldarfjórđungur frá pví ađ fyrsta rannsókn höfunda á hlutverki skólastjóra í grunnskólum hér á landi var gerđ. Á pessum tímamótum er pví áhugavert ađ fá innsýn í pađ hvernig skólastjórar í grunnskólum líta á hlutverk sitt sem faglegir leiđtogar og hvađa breytingar hafa orđið á sýn peirra á pessum 25 árum. Markmið pessarar rannsóknar var að kanna hvađa gildi skólastjórar segjast einkum leggja til grundvallar í starfi sínu og hvernig peir forgangsrađa mikilvægum viðfangsefnum.

\section{FRFEILEGT SAMHENGI}

\section{Gildi og forysta}

Gildi eru páttur í persónugerđ sérhverrar manneskju. Flestir sem međvitađir eru um eigin gildi virðast taka pau mjög alvarlega og vera reiðubúnir að berjast fyrir peim í orđi og athöfnum. Gildi eru grundvöllur peirrar afstöðu sem fólk tekur varðandi pað að hverju sé mikilvægast að stefna í lífinu, (Gold, 2004; Sigrún Ađalbjarnardóttir, 2006). Gildin hafa einnig áhrif á hegđun fólks, hvort sem pađ áttar sig á pví eđa ekki (Begley, 2004; Gunnar E. Finnbogason og Gunnar J. Gunnarsson, 2006). Begley (2003) telur að allir leiðtogar styðjist meðvitað eða ómeðvitað við gildi pegar peir greina aðstæður og ákveđa viðbrögð við peim.

Gildin berast frá einni kynslóð til annarrar með félagsmótun. Fræđimenn telja að einstaklingar tileinki sér gildi á unga aldri út frá reynslu og međ samskiptum sínum við fjölskyldu og félaga (Begley, 2004; Branson, 2005; Gunnar E. Finnbogason, 2004). Merkingin sem einstaklingar leggja í tiltekna reynslu og túlkun peirra á henni ræđur úrslitum um pað 
hvaða gildi peir tileinka sér. Fæstir eru meðvitađir um eigin gildi (Branson, 2005) og margir eiga pví í erfiðleikum með að lýsa eigin gildum pegar eftir er leitað.

petta er meginástæđan fyrir pví að talsverđur munur og ósamræmi getur verið milli yfirlýstra gilda (e. espoused values) einstaklings og raunverulegra (e. actual values) gilda eins og pau birtast í athöfnum viðkomandi (Branson, 2005; Bussey, 2006). Stjórnandi getur t.d. lýst pví ítrekað yfir að umhyggja og samstarf séu leiðarljós hans í starfi en mat samstarfsfólks verið að viðkomandi sé ónærgætinn og einráđur. Petta ósamræmi milli yfirlýstra gilda og peirra sem birtast í atferli getur valdið bæđi stjórnandanum sjálfum og samstarfsfólki hans vandræðum (Begley, 2004; Tuana, 2007). Slíkt ósamræmi veldur pví m.a. að leiðtoginn virđist ótrúverðugur.

Síđustu áratugi hafa fræđimenn lagt áherslu á ađ siđferđi sé kjarni og undirstađa forystunnar (Hodgkinson,1991; Sigurđur Kristinsson, 2014). Stjórnendur eru hvattir til að ígrunda og gera sér grein fyrir eigin gildum pví slík sjálfspekking geri peim kleift að starfa af heilindum (e. authenticity) og halda samræmi milli orða og athafna (Begley, 2003; Crippen, 2012; Duignan, 2003). Leiđtogar sem búa yfir slíkri sjálfspekkingu hafa hæfileikann til að greina og velta fyrir sér eigin gildum, stađfesta pau eđa endurskođa pannig að gildin geti verið peim raunveruleg leiðsögn í lífi og starfi (Branson, 2009). Slík gildagrunduð (e. value based) forysta telst vera af siðferðilegum toga. Ígrundun af pessu tagi er mikilvæg pví pótt gildin séu talin fremur stöđugur páttur í persónugerđ fólks, pá hefur lífsreynsla áhrif á gildi og skođanir einstaklinga (Gold, 2004).

Eftir efnahagshrunið 2008 var einmitt lögð mikil áhersla á að stjórnendur störfuðu af heilindum, pað er að orð og athafnir færu saman. Í pessu samhengi bentu peir Branson og Gross (2014) á аð „hin alpjóđlega fjármálakreppa hafi beint kastljósinu að forystu á siðferđilegum grunni á heimsvísu“ (bls. 1). Gildi, heilindi og siðferđi urđu lykilhugtök í umræðu og fræđilegri umfjöllun um forystu bæđi í stjórnmálum og atvinnulífi og bent var á að ekki væri nóg að athafnir væru löglegar ef pær væru siðlausar (Begley, 2010; Branson, 2009; Branson og Gross, 2014; Bredeson, 2005; Crippen, 2012).

Bent hefur verið á að stjórnendur stofnana og fyrirtækja kunni að purfa ráđgjöf til að átta sig á eigin gildum vegna pess að fólk geri sér of sjaldan skýra grein fyrir peim. Branson (2007) gerđi rannsókn par sem hann aðstođađi viðmælendur við að efla siðferđisvitund sína. Hann tók viðtöl við sex skólastjóra í grunnskólum (e. primary schools) í Brisbane í Ástralíu. Viđmælendur voru beđnir að ígrunda sjálfið sem Branson skiptir í sjálfsmynd, sjálfsvirđingu, hvata, skođanir og gildi. Allir pessir pættir mótast af lífsreynslu á ýmsum tímabilum ævinnar en eru fólki oft hvorki međvitađir né ađgengilegir í daglegu lífi. Branson aðstoðaði viðmælendur við að rifja upp við hvaða aðstæður og hvers vegna peir hefđu tileinkađ sér sín yfirlýstu gildi og ígrunda hvort peir væru sáttir við að pessi gildi væru peim leiđarljós í starfi. pessi ađferđ reyndist vera tímafrek og gerđi miklar kröfur um heiđarlega sjálfsskođun. Skólastjórarnir voru samt sammála um að hún hefđi nýst peim vel til aukinnar sjálfspekkingar og um leið styrkt pá í samskiptum við ađra. Pessari ađferð svipar til peirrar sem Burns (1978) lýsti áratugum áđur pegar hann hvatti til pess að verðandi skólastjórar hefðu „mentor“ sem ađstođađi pá við að efla siðferđilega afstöđu sína.

Lengi hefur mátt greina áherslur á sameiginlega sýn, markmið og gildi í skólastarfi í fræðilegum skrifum um menntastjórnun (Bass, 1999; Campell, Gold og Lunt, 2003; Sergiovanni, 2009). Slík afstaða hefur verið talin forsenda pess að unnið sé markvisst að 
settum markmiðum og pannig megi tryggja sem bestan árangur skólastarfs. Í fræðilegum skrifum er algengt að rætt sé um skólamenningu í pessu samhengi og henni lýst sem safni sameiginlegra gilda, viðmiða og afstöđu (Hoy og Miskel, 2008).

Oft er pó tekist á um hvađa gildi skuli hafa ađ leiđarljósi og láta ráđa för. Í rannsókn á áhrifum kreppunnar á skólastarf (Steinunn Helga Lárusdóttir, Anna Kristín Sigurđardóttir, Arna H. Jónsdóttir, Börkur Hansen og Guđný Guđbjörnsdóttir, 2015) kom t.d. fram að starfsmenn skóla töldu að gildin sem yfirvöld hefðu að leiðarljósi við niðurskurð á fjárframlögum til skóla eftir hrun gengju gegn peirra eigin. Sjálfir lögđu peir megináherslu á börnin og hollustu sína við pau. Í viðtölum við starfsmenn voru siđferđilegu gildin, umhyggja, jafnrétti og réttlæti, áberandi, enda voru petta yfirlýst gildi peirra. Hagræđing var hins vegar eitt af yfirlýstum gildum yfirvalda. Slík gildi eru af stjórnsýslulegum toga með sterkum efnahagslegum undirtóni. Pessar niðurstöđur eru vísbending um að gildi hagsmunađila skóla, foreldra, nemenda, skólayfirvalda og kennara fari ekki ævinlega saman jafnvel pótt peir tilheyri sama menningarsvæði, sveitarfélagi eđa jafnvel sama skóla. Við slíkar aðstæður reynir mjög á skólastjórann, sýn hans á hlutverk sitt, pekkingu á eigin gildum og annarra og trausta siðferđilega dómgreind.

Begley (2004) bendir á að sameiginleg afstađa og gildi séu ekki mikilvægust í pessu samhengi. Hafa verđi í huga að flest vestræn ríki teljist vera fjölmenningarleg. Ekki sé sjálfgefið að fólk af ólíkum uppruna og međ ólíka trúhneigð og hefđir geti sammælst um gildi. Meira máli skipti að auka sjálfspekkingu hvers og eins og að skilja afstöðu annarra pannig að áhrifa sem flestra gæti í skólastarfinu. Óráđlegt er pví talið að koma sér hjá að ræða ólík sjónarmið og gildi. Sama afstađa kemur fram hjá peim Lumby með Coleman (2007) sem mæla ekki með pví að forystan beinist að pví að fá alla til að sameinast um sömu sýn og gildi. Farsælla sé að ræđa opinskátt um mismunandi sýn og gildi í peim tilgangi að hlúa að margbreytileikanum, enda er „samtalið ... eitt mikilvægasta verkfærið í lýðræðislegu samstarfi“ (Gunnar E. Finnbogason, 2004, bls. 180).

\section{Hlutverk og viðfangsefni}

Lögum samkvæmt gegnir skólastjóri faglegu forystuhlutverki í skólastarfinu (lög um grunnskóla, nr. 91/2008; Mennta- og menningarmálaráđuneyti, 2012). Honum er ætlað að eiga frumkvæði að breytingum í skólastarfinu og leiða pær og vinna peim brautargengi međal starfsfólks (Fullan 2016; Hoy og Miskel, 2008; Matthews og Crow, 2010). Hlutverk skólastjóra spannar vítt svið af bæđi faglegum og rekstrarlegum toga og peir purfa að geta unnið að margvíslegum viðfangsefnum.

Hverjum og einum skólastjóra er að mestu í sjálfsvald sett að móta hlutverk sitt á grundvelli laga og reglna. Hann ákveđur hvađa meginhlutverki hann gegnir, hvađa verkefni hann setur í forgang og hverjum hann úthlutar öđrum. Í skýrslu OECD um markvissari forystu í skólastarfi (Pont, Nusche og Moorman, 2008) er bent á mikilvægi pess að í stefnumörkun skólastarfs sé lögđ áhersla á ađ efla sjálfstæđi skólastjóra og veita peim nauđsynlegan stuðning međ ráđgjöf og tækifærum til endurmenntunar. Pont og félagar telja að meginhlutverk skólastjóra og ábyrgð eigi að beinast að pví ađ hafa áhrif á nám nemenda og bæta árangur peirra. 
Starfshættir skólastjóra við íslenska grunnskóla síðasta aldarfjórðung hafa talsvert verið rannsakađir. Forgangsröđun viðfangsefna hefur t.a.m. verið könnuð prisvar sinnum međal skólastjóra í grunnskólum međ spurningalistakönnunum (Börkur Hansen, Ólafur H. Jóhannsson og Steinunn Helga Lárusdóttir, 1994, 2004 og 2008). Einnig var spurt um atriđi sem voru ofarlega á baugi hverju sinni og tengdust skólastarfi, svo sem breytingar á lagaumhverfi og starfsskyldum skólastjóranna. Pessar rannsóknir á forgangsröđun hafa að mestu takmarkast við raunverulega og ákjósanlega forgangsröđun viðfangsefna peirra á grundvelli flokkunar McClearys og Thomsons (1979) á bandarískum skólastjórum. Viðfangsefnin sem pau athuguðu féllu í eftirfarandi flokka: vinna skólastjóra sem beinist að námskrárvinnu, starfsfólki, stjórnun/umsýslu, málefnum nemenda, skólahverfinu, skólaskrifstofu/fræđsluyfirvöldum og endurnýjun i starfi. Athugađ var hvernig skólastjórar vörðu tíma sínum (raunverulegur tími) og hvernig peir hefðu kosið að verja tíma sínum (æskilegur tími) til verkpátta er falla að framangreindum flokkum.

Rannsóknir Barkar Hansen, Ólafs H. Jóhannssonar og Steinunnar Helgu Lárusdóttur (1994, 2004, 2008) veita innsýn í pađ hvernig skólastjórar í grunnskólum verja og vildu verja tíma sínum til framangreindra málaflokka en gögnum var safnað 1991, 2001 og 2006. Öll árin segjast peir verja mestum tíma í páttinn stjórnun/umsýsla, pað er viðfangsefni sem snúa að fjármálum, rekstri og skrifstofuhaldi. pá kemur einnig fram að peir vildu gjarnan verja minni tíma til pessa páttar. Öll árin er á hinn bóginn námskrárvinna í fyrsta sæti hjá skólastjórum yfir bađ sem peir helst vildu verja tíma sínum í, p.e. viđfangsefni sem tengjast próun námskrár, kennsluháttum, kennsluskipulagi, námsefni og viðlíka verkpáttum. Petta virđist vera vísbending um að málefni tengd kennslu séu ekki í forgrunni í viđfangsefnum skólastjóra í jafnmiklum mæli og peir sjálfir helst kysu og löggjafinn gerir ráđ fyrir (lög um grunnskóla nr. 91/2008). Sömu höfundar (2008) benda einnig á að pátturinn starfsfólk færist úr pví að vera í fimmta sæti í ákjósanlegri röð viðfangsefna í könnuninni 1991 og upp í annađ sæti 2001, en par er starfsfólk einnig í öđru sæti í raunverulegri röđun viðfangsefna. Með starfsfólki er átt við verkefni eins og ráđningar, ráđgjöf, mat og stuđning við starfsmenn skólans. Pessi áhersla á starfsfólk kom einnig skýrt fram í rannsókn peirra Birnu Sigurjónsdóttur og Barkar Hansen (2014) á gildum skólastjóra í Reykjavík. Í viðtölum við skólastjórana kom fram að peir lögðu mikla áherslu á velferð og líđan jafnt starfsmanna sem nemenda. Petta töldu höfundar vera einn mesta styrkleika skólastjóranna.

Samkvæmt pessum niðurstöðum hefur röđun viðfangsefna skólastjóra breyst nokkuð á peim tíu árum sem líđa milli fyrstu og annarrar könnunar. Einnig kemur fram að skólastjórar hafi í lok pessa tímabils variđ meiri tíma í vinnu tengda starfsfólki en áđur. Eigi аð síđur eru pað viðfangsefni sem snúa að fjármálum, rekstri og skrifstofuhaldi sem skólastjórar verja mestum tíma í en viðfangsefni tengd próun námskrár, kennsluháttum, kennsluskipulagi, námsefni og viðlíka verkpáttum pađ sem peir vildu verja tíma sínum í. pađ eru pví stjórnunarleg viđfangsefni sem peir setja í forgrunn í störfum sínum fremur en kennslufræðileg. 
Pessar rannsóknir á verksviđum skólastjóra hér á landi eru áhugaverđar, m.a. í ljósi pess hve fáar sambærilegar rannsóknir virđast hafa verið gerđar á pessu efni. Í pessu sambandi benda peir Horng, Klasik og Loeb (2010) á ađ prátt fyrir mikla umfjöllun og rannsóknir á mikilvægi skólastjóra fyrir gæđi skólastarfs sé til pess að gera lítið um rannsóknir á pví hvað pađ er sem peir eru einkum ađ fást viđ í daglegum störfum.

Rannsókn Horng o.fl. (2010) er byggð á athugunum (e. observations) og skráningum međal 65 skólastjóra í stóru fylki í Bandaríkjunum međ fjölbreytilegri flóru skóla. Höfundar segja að skólastjórarnir hafi variđ mestum tíma sínum í stjórnunarleg viđfangsefni „til að halda skólanum gangandi“ eđa um 30\% (bls. 502). Pá hafi peir varið um 20\% af tíma sínum í atriði sem tengjast fjármálum, rekstri og starfsmannahaldi og um 15\% í samskipti innan skólans og 5\% við ytri ađila. Fram kemur að skólastjórarnir verja minnstum tíma til verkefna sem beinast að námi og kennslu, p.e. $6 \%$ til verkefna á vettvangi, svo sem heimsókna í bekki og ráđgjafar til kennara og $7 \%$ til verkefna eins og mats á námi og kennslu og skipulags starfspróunarverkefna. Dá fóru um 20\% af tíma peirra í annađ. Höfundar segja að pað hafi komið á óvart hve litlum tíma skólastjórarnir vörðu í að sinna kennslufræđilegum verkefnum en minna á að sum verkefni taki meiri tíma en önnur og að tími sem varið sé í verkefni purfi ekki að endurspegla mikilvægi peirra. Pessar niðurstöður eru um margt samhljóđa pví sem rannsóknir hér á landi hafa leitt í ljós.

Trausti Porsteinsson og Amalía Björnsdóttir (2016) könnuđu bakgrunn og starfsaðstæður skólastjóra í grunnskólum og hvađa viðfangsefni i stjórnkerfi skólanna peir kysu að takast á við. pau segja niðurstöðurnar „vekja áleitnar spurningar um pað hvers vegna skólastjórar, í ljósi víðtækrar menntunar peirra og reynslu, sinni frekar stjórnun en faglegri forystu“ (bls. 507). Pessar niðurstöður Trausta og Amalíu eru pví einnig um margt samhljóđa pví sem fyrri rannsóknir hafa leitt í ljós.

Á grundvelli samantektar á fjölmörgum rannsóknum á tengslum milli áhrifa skólastjóra og námsárangurs segir Robinson (2011) að fjórir pættir sýni sterk marktæk tengsl: Setja fram markmið og móta væntingar (.42), afla bjarga kerfisbundið (.31), tryggja gæðakennslu (.42), veita forystu um nám og starfspróun kennara (.84) og tryggja skipulagt og öruggt umhverfi (.27). Samkvæmt pessu er áhrifamesti pátturinn forysta um nám og starfspróun kennara. Að mati Robinson er æskilegt að gera nám og starfspróun kennara að samábyrgu verkefni pví kennarar séu innbyrđis háđir hver öđrum.

í ljósi pess sem að framan greinir er mikilvægt ađ athuga á hvađa gildi skólastjórar segjast leggja áherslu í störfum sínum og hvernig peir forgangsrađa helstu viðfangsefnum sínum. Eftirfarandi spurningar voru settar fram til ađ leiđa rannsóknina: Á hvađa gildi segjast skólastjórar í grunnskólum leggja áherslu í störfum sínum? Hvernig forgangsrađa peir helstu viðfangsefnum sínum? Hvađa breytingar má greina í forgangsröđun viðfangsefna á tímabilinu 1991-2017? Til samanburđar eru notuð gögn úr fyrri rannsóknum höfunda. 


\section{AĐFERĐ}

Afstađa skólastjóra til gilda sem tengjast skólastarfi var könnuð með spurningalista. Gildin voru fundin með pví að greina lög, reglugerđir og námskrár. Kortlagning helstu gilda í pessum gögnum er ekki tæmandi en er gerđ til að fá yfirlit yfir helstu gildi sem par má finna. Skólastjórarnir voru beđnir að gefa hverju gildi stig frá 1 upp í 10 eftir pví hversu mikla áherslu peir legðu á viðkomandi gildi í störfum sínum.

Forgangsröđun viðfangsefna var byggð á flokkun McClearys og Thomsons (1979). Í fyrri rannsóknum hér á landi á starfsháttum skólastjóra í grunnskólum var stuđst við sömu flokkun, p.e. í rannsóknum sem gerđar voru 2006, 2001 og 1991 (Börkur Hansen o.fl., 1994, 2004, 2008). Viđfangsefnin sem um ræđir eru vinna skólastjóra við námskrárvinnu, starfsfólk, stjórnun/umsýslu, málefni nemenda, skólahverfiđ, skólaskrifstofu/fræđsluyfirvöld og endurnýjun í starfi. Að pessu sinni var einum flokki viðfangsefna bætt við, p.e. námsađlögun fyrir nemendur almennt, nemendur međ sértæka námsörđugleika, nemendur sem hafa ekki íslensku að móđurmáli o.fl., en vísbendingar eru um að viðfangsefni sem falla undir pennan flokk tengist störfum skólastjóra í auknum mæli (Börkur Hansen, Sigurlaug Hrund Svavarsdóttir, Helgi P. Svavarsson og Hanna Ragnarsdóttir, 2016; Helgi P. Svavarsson, Börkur Hansen, Samúel Lefever, Hafdís Guđjónsdóttir og Hanna Ragnarsdóttir, 2016). Kannađ var hvernig skólastjórar vörđu tíma sínum (raunverulegur tími) og hvernig peir hefðu kosið að verja tíma sínum (æskilegur tími) til framangreindra viðfangsefna. Peir voru beđnir að setja pað viðfangsefni sem tók mestan tíma í fyrsta sæti, pað sem tók næstmestan tíma í annað sæti og pannig áfram.

Vorið 2017 var spurningalistinn sendur á rafrænu formi á netföng allra starfandi skólastjóra í grunnskólum landsins, samtals 162. Menntavísindastofnun sá um gerđ, fyrirlögn og úrvinnslu spurningalistans. Spurningalistinn var forprófađur tvisvar sinnum með pví að leggja hann fyrir fjóra ađstođarskólastjóra hvoru sinni. Fjórar ítrekanir voru sendar. Alls bárust 111 svör og er svarhlutfall pví 69\%. Svarendum var heitið trúnađi og við úrvinnslu komu nöfn svarenda hvergi fram. Spurningalistinn var gerður í Qualtrics og úrvinnslan í forritunum SPSS og EXCEL.

Gera má ráđ fyrir ađ sú forgangsröđ sem skólastjórar vilja hafa á helstu viđfangsefnum sínum hafi einhvern samhljóm við yfirlýst gildi peirra. Ekki er hins vegar hægt að álykta nokkuð um samspil raunverulegrar röđunar og raunverulegra gilda vegna pess að skólastjórarnir voru einir til frásagnar um pađ hvađa gildi peir legđu áherslu á; ekki voru gerđar athuganir á atferli peirra. Ekkert er pví hægt að fullyrđa um pað hvort yfirlýst gildi peirra eru í samræmi við pau sem endurspeglast í atferli skólastjóranna. peir gætu verið illa læsir á eigin gildi og annarra og pví ekki meðvitađir um pau gildi sem hafa áhrif á störf peirra. Peir væru pá á sama báti og ýmsir starfsfélagar peirra sem fræđimenn hafa skrifađ um (Begley, 2004; Branson, 2005; Tuana, 2007). 


\section{NIĐURSTÖĐUR}

Hér á eftir verða niðurstöđur rannsóknarinnar kynntar. Fyrst er dregin upp mynd af aðstæðum í skólunum, en hlutverk og viðfangsefni stjórnenda mótast međal annars af aðstæðum á hverjum stađ, s.s. skólagerð, skólastærð, ríkjandi kennslufyrirkomulagi o.fl. sem getur haft áhrif á starfsumhverfi skólastjóra. Pá er greint frá peim gildum sem skólastjórar í grunnskólum segjast leggja áherslu á í störfum sínum. Næst er dregin upp mynd af pví hvernig peir forgangsrađa helstu viðfangsefnum, p.e. hvernig peir vörđu tíma sínum og hvernig peir hefðu kosið að verja tíma sínum til peirra viðfangsefna sem könnuð voru. Forgangsröđun viðfangsefna er svo skođuð á grundvelli nokkurra pátta er taka til mismunandi ađstæđna í skólunum.

\section{Að̌stæơur}

Eins og áđur segir svöruđu 111 skólastjórar í grunnskólum spurningalistanum, sem er 69\% svarhlutfall. Um 38\% svarenda voru karlar og 62\% konur. Um 38\% skólastjóranna eru með framhaldsnám í stjórnun og 16\% međ framhaldsnám af öđru tagi. Flestir starfa í skólum sem eru heildstæðir (1.-10. bekkur) eđa um 97\%. Um 24\% skólanna eru á Stór-Reykjavíkursvæđinu (8\% í Reykjavík og 16\% á höfuđborgarsvæđinu utan Reykjavíkur) og 76\% á öđrum svæðum landsins.

Stærð skólanna er talsvert mismunandi, en 35\% skólanna eru með 100 eđa færri nemendur, 30\% með 101-300 nemendur, 17\% með 301-500 nemendur og 19\% með 501 eða fleiri nemendur. Pá voru 73\% skólanna með 20 eđa færri ađra starfsmenn og um 27\% með 21-60 aðra starfsmenn. Um tveir priðju peirra skóla sem voru með 20 eđa færri ađra starfsmenn voru með 149 nemendur eđa færri. í 70\% skólanna var fjöldi nemenda með sértæka námsörđugleika 30 eđa færri, 17\% skólanna međ 31-90 og 13\% skólanna međ 91 eđa fleiri nemendur međ sértæka námsörđugleika.

Bekkjarkennsla (kennsla í höndum umsjónarkennara eđa faggreinakennara) var ráđandi kennslufyrirkomulag í 38\% skólanna, teymiskennsla (tveir eđa fleiri kennarar samábyrgir fyrir kennslu í árgangi eđa aldursblönduđum hópi að öllu leyti eđa að hluta) i 11\% skólanna, og blandađir kennsluhættir (blanda af bekkjarkennslu og teymiskennslu) í 39\% skólanna. Annađ fyrirkomulag var í 11\% skólanna.

\section{Gildi}

Afstađa skólastjóranna til 23 gilda sem tengjast skólastarfi var könnuð pannig að skólastjórarnir voru beđnir ađ gefa hverju gildi stig frá 1 upp i 10 eftir pví hversu mikla áherslu peir legđu á viðkomandi gildi í störfum sínum. Tafla 1 sýnir áherslu skólastjóranna á sex gildi sem flokka má af siðferđilegum toga (e. moral values) og sex af stjórnsýslulegum toga (e. managerial values). 
Tafla 1. Gildi - áherslur skólastjóra

\begin{tabular}{|l|c|c|c|}
\hline Gildi & $\begin{array}{c}\text { Stig 1-4 } \\
\text { \% }\end{array}$ & $\begin{array}{c}\text { Stig 5-7 } \\
\text { \% }\end{array}$ & $\begin{array}{c}\text { Stig 8-10 } \\
\text { \% }\end{array}$ \\
\hline Siðferđileg: & & & 95 \\
\hline Umhyggja & 3 & 2 & 90 \\
\hline Jafnrétti & 2 & 8 & 92 \\
\hline Lýðræđi & 2 & 6 & 93 \\
\hline Sjálfstæđi & 2 & 4 & 95 \\
\hline Umburðarlyndi & 3 & 2 & 96 \\
\hline Réttlæti & 2 & 2 & 9 \\
\hline Stjórnsýsluleg: & & & 82 \\
\hline Samkeppni & 51 & 41 & 44 \\
\hline Skilvirkni & 1 & 17 & 91 \\
\hline Hagræđing & 3 & 44 & 67 \\
\hline Ábyrgđarskylda & 2 & 6 & 91 \\
\hline Afköst & 2 & 31 & 7 \\
\hline Árangur & & & \\
\hline
\end{tabular}

Samkvæmt töflu 1 segjast nánast allir skólastjórarnir leggja mikla áherslu á siđferđileg gildi í störfum sínum, en um 94\% peirra gefa peim 8-10 stig. Ekki eru hér tilgreindar fleiri niðurstöður um gildi af siðferðilegum toga enda var stigagjöf skólastjóranna fyrir áherslur par nánast eins, p.e. yfir 90\% peirra gáfu peim 8-10 stig.

Öđru máli gegnir um gildi af stjórnsýslulegum toga. Fæst stig í peim flokki gilda fær samkeppni en 9\% skólastjóranna gefa par 8-10 stig og hagræđing sem 44\% skólastjóranna gefa 8-10 stig. Aftur á móti segjast yfir 90\% skólastjóranna leggja mikla áherslu á ábyrgđarskyldu og árangur í störfum sínum.

\section{Forgangsröðun viðfangsefna}

Í töflu 2 á næstu blađsíđu sést hvernig skólastjórarnir forgangsröđuđu helstu viðfangsefnum vorið 2017, p.e. hvernig peir vörđu tíma sínum (raunveruleg röđun) og hvernig peir hefðu kosið að verja tíma sínum (ákjósanleg röđun) til peirra viðfangsefna sem könnuð voru. Til upplýsingar eru einnig birtar niðurstöður úr sambærilegum könnunum sem gerđar voru 2006, 2001 og 1991. Rétt er að árétta að viðfangsefninu námsađlögun var bætt við í könnuninni 2017. 
Tafla 2. Forgangsröđun viðfangsefna árin 2017, 2006, 2001 og 1991

\begin{tabular}{|c|c|c|c|c|c|c|c|c|}
\hline \multirow[b]{2}{*}{ Viðfangsefni/málaflokkur: } & \multicolumn{4}{|c|}{ Raunveruleg röðun } & \multicolumn{4}{|c|}{ Ákjósanleg röðun } \\
\hline & 2017 & 2006 & 2001 & 1991 & 2017 & 2006 & 2001 & 1991 \\
\hline $\begin{array}{l}\text { Námskrárvinna (vinna við fram- } \\
\text { kvæmd ađalnámskrár, skólanámskrá, } \\
\text { sjálfsmat skóla, próunarverkefni og } \\
\text { önnur störf er varđa kennsluhætti, } \\
\text { kennsluskipulag, námsefni o.fl.) }\end{array}$ & 3 & 4 & 5 & 2 & 1 & 1 & 1 & 1 \\
\hline $\begin{array}{l}\text { Starfsfólk (ráđningar, ráđgjöf og } \\
\text { stuđningur, mat o.fl.) }\end{array}$ & 2 & 2 & 3 & 5 & 3 & 2 & 5 & 6 \\
\hline $\begin{array}{l}\text { Stjórnun/umsýsla (rekstur, skrifstofu- } \\
\text { hald, fjármál, bréfaskriftir, skýrslugerđ } \\
\text { o.fl.) }\end{array}$ & 1 & 1 & 1 & 1 & 7 & 7 & 6 & 5 \\
\hline $\begin{array}{l}\text { Málefni nemenda (fundir međ nem- } \\
\text { endum, ráđgjöf, skipulagsvinna vegna } \\
\text { félagsstarfa, nemendaverndarráð, } \\
\text { barnavernd, samstarf við foreldra } \\
\text { o.fl.) }\end{array}$ & 4 & 5 & 2 & 3 & 2 & 4 & 4 & 3 \\
\hline $\begin{array}{l}\text { Hegðun nemenda (skólareglur, } \\
\text { mætingar, hegðunarvandkvæði, sam- } \\
\text { starf um úrausnir o.fl.) }\end{array}$ & 6 & 6 & 4 & 4 & 9 & 9 & 9 & 8 \\
\hline $\begin{array}{l}\text { Skólahverfið (fundir međ skólaráđi, } \\
\text { samtökum foreldra og foreldraráđi, } \\
\text { viðræđur við foreldra, ráđgjafa og full- } \\
\text { trúa ýmissa hagsmunahópa) }\end{array}$ & 9 & 8 & 8 & 7 & 8 & 6 & 7 & 7 \\
\hline $\begin{array}{l}\text { Skólaskrifstofa/fræðsluyfirvöld } \\
\text { (fundir, nefndarstörf, skýrslugerð, } \\
\text { upplýsingagjöf o.fl.) }\end{array}$ & 8 & 7 & 7 & 9 & 10 & 8 & 8 & 9 \\
\hline $\begin{array}{l}\text { Endurnýjun í starfi (lestur fræđibóka } \\
\text { og greina, námskeið, ráđstefnur o.fl.) }\end{array}$ & 10 & 9 & 9 & 8 & 4 & 5 & 3 & 4 \\
\hline $\begin{array}{l}\text { Áætlanagerð (skipulagsvinna og } \\
\text { áætlanagerð til langs tíma (t.d. hálft } \\
\text { til eitt ár) svo sem starfsáætlun fyrir } \\
\text { næsta skólaár, áætlanir um byggingar } \\
\text { og viðhald, endurmenntun starfs- } \\
\text { manna o.fl.) }\end{array}$ & 5 & 3 & 6 & 6 & 5 & 3 & 2 & 2 \\
\hline $\begin{array}{l}\text { Námsaðlögun (fyrir nemendur } \\
\text { almennt, nemendur með sértæka } \\
\text { námsörðugleika, nemendur sem hafa } \\
\text { ekki íslensku að móðurmáli, o.fl.) }\end{array}$ & 7 & & & & 6 & & & \\
\hline
\end{tabular}


Stjórnun/umsýsla er í fyrsta sæti yfir raunverulega röðun viðfangsefna vorið 2017. pað er sama niðurstađa og í fyrri könnunum 2006, 2001 og 1991. Starfsfólk er í öđru sæti eins og 2006 en var í fimmta sæti 1991. Námskrárvinna er í priðja sæti 2017, öđru sæti 1991 en fimmta sæti 2001. Viðfangsefnið námsaðlögun sem var bætt við 2017 skipast í sjöunda sæti yfir raunverulega röđun verkefna.

Eins og áđur er námskrárvinna í fyrsta sæti yfir ákjósanlega röđun viđfangsefna. Málefni nemenda er í öđru sæti. Starfsfólk er í priðja sæti en var í sjötta sæti 1991. Námsaðlögun er í sjötta sæti yfir ákjósanlega röđun verkefna. Athygli vekur að áætlanagerð er í fimmta sæti af tíu yfir ákjósanlega röđun viðfangsefna vorið 2017 en var í öđru sæti 1991 og 2001.

Til að öđlast dýpri skilning á pví hvernig skólastjórarnir verja tíma sínum var forgangsröðun viðfangsefna athuguð með hliðsjón af nokkrum ađstæðubundnum páttum í skólunum. Kannađ var hvort eftirfarandi pættir hefðu áhrif á forgangsröđun skólastjóranna:

- Kyn.

- Skólastærđ: 99 nemendur og færri, 100-299 nemendur, 300 nemendur og fleiri.

- Stađsetning skóla eftir landsvæðum: höfuðborgarsvæðið, landsbyggð.

- Fjöldi annarra starfsmanna en kennara: 20 eđa færri starfsmenn í skólum með 100299 nemendur; 20 eða fleiri starfsmenn í skólum með 300 eða fleiri nemendur.

- Fjöldi nemenda međ sértæka námsörđugleika: 30 eđa færri nemendur međ sértæka námsörđugleika í skólum međ 100-299 nemendur; 61 eđa fleiri nemendur með sértæka námsörđugleika í skólum međ 300 eđa fleiri nemendur.

- Ríkjandi kennslufyrirkomulag: bekkjarkennsla (bekkjarkennsla í höndum umsjónarkennara eđa faggreinakennara), teymiskennsla (tveir eđa fleiri kennarar samábyrgir fyrir kennslu í árgangi eđa aldursblönduđum hópi, ađ öllu leyti eđa hluta), blandađir kennsluhættir (blanda af bekkjarkennslu og teymiskennslu).

Enginn munur kom fram á raunverulegri og ákjósanlegri forgangsröđun viðfangsefna eftir kyni. Örlítill munur var á forgangsröđun viðfangsefna eftir skólastærð, p.e. raunveruleg forgangsröđun allra viðfangsefna var nánast eins utan pess að námsađlögun var í níunda sæti í skólum međ 300 nemendur og fleiri en í sjöunda sæti í skólum í hinum stærðarflokkunum, og ákjósanleg forgangsröđun viðfangsefna var nánast eins í öllum tilvikum fyrir utan pað að endurnýjun í starfi var í öđru sæti í skólum með 99 nemendur eđa færri, í 6. sæti í skólum međ 100-299 nemendur og fjórđa sæti í skólum með 300 og fleiri nemendur.

Forgangsröđun viđfangsefna var einnig nánast óháđ stađsetningu skóla fyrir utan pað að í skólum á höfuđborgarsvæđinu var námskrárvinna í fjórđa sæti og námsađlögun í níunda sæti í raunverulegri forgangsröđun, en í öđru og sjöunda sæti á landsbyggđinni. Ekki var heldur mikill munur á ákjósanlegri forgangsröđun fyrir utan pađ að á höfuðborgarsvæđinu var námskrárvinna í níunda sæti og hegđun nemenda í sjöunda sæti en á landsbyggđinni í sjöunda og níunda sæti. 
Smávægilegur munur kom fram á raunverulegri forgangsröđun viðfangsefna hjá skólastjórunum eftir fjölda annarra starfsmanna en kennara. Í skólum međ 20 eđa færri ađra starfsmenn međ 100-299 nemendur var námskrárvinna í öđru sæti, starfsfólk í fjórđa sæti og námsaðlögun í sjöunda sæti en í skólum međ 20 starfsmenn eđa fleiri og međ 300 eđa fleiri nemendur í fjórđa, öđru og níunda sæti. Dá var nánast enginn munur á ákjósanlegri forgangsröđun fyrir utan pað að í skólum með 20 eða færri aðra starfsmenn með 100-299 nemendur var endurnýjun í starfi í sjöunda sæti en í skólum með 20 starfsmenn eða fleiri og með 300 eđa fleiri nemendur í priðja sæti.

Enginn munur kom fram á raunverulegri forgangsröđun viðfangsefna eftir fjölda nemenda með sértæka námsörđugleika. Smávægilegur munur kom fram á ákjósanlegri forgangsröđun, en í skólum međ 30 eđa færri nemendur međ sértæka námsörđugleika með 100-299 nemendur var stjórnun/umsýsla í sjötta sæti og endurnýjun i starfi í sjöunda sæti en í níunda og fjórđa sæti í skólum međ 300 eđa fleiri nemendur.

Svolítill munur kom fram á raunverulegri forgangsröđun viðfangsefna eftir ríkjandi kennslufyrirkomulagi, en í bekkjarkennsluskólum var starfsfólk í öđru sæti, í teymiskennsluskólum í fyrsta sæti og í fjórđa sæti í skólum međ blandađa kennsluhætti. pá var skólahverfið í níunda sæti í bekkjarkennsluskólum og skólum međ blandađa kennsluhætti en í sjöunda sæti í teymiskennsluskólum. Dálítið meiri munur kom fram á ákjósanlegri röđun viđfangsefna en námskrárvinna var í priđja sæti í bekkjarkennsluskólum og skólum með blandaða kennsluhætti en í fimmta sæti í teymiskennsluskólum. Námsađlögun var í fjórđa sæti í bekkjarkennsluskólum, áttunda sæti í teymiskennsluskólum og fimmta sæti í skólum međ blandađa kennsluhætti. Endurnýjun í starfi var í sjötta sæti í bekkjarkennsluskólum, priđja sæti í teymiskennsluskólum og fjórđa sæti í skólum með blandađa kennsluhætti. Pá var áætlanagerð í fimmta sæti í bekkjarkennsluskólum, fjórđa sæti í teymiskennsluskólum og sjötta sæti í skólum með blandaða kennsluhætti.

\section{UMRÆEA}

Markmið pessarar rannsóknar var að kanna hvađa gildi skólastjórar segjast einkum leggja til grundvallar í starfi sínu og hvernig peir forgangsrađa mikilvægum viðfangsefnum. Skólastjórarnir voru spurđir um pau gildi sem peir hefðu að leiðarljósi í störfum sínum, p.e. yfirlýst gildi peirra, og peir beđnir að forgangsrađa tíu mikilvægum viðfangsefnum.

Gera má ráđ fyrir að sú forgangsröð sem skólastjórar vilja hafa á helstu viðfangsefnum sínum samræmist yfirlýstum gildum peirra. Í fyrri hluta umræđukaflans er fjallađ um pá tvo flokka gilda sem skólastjórarnir voru beđnir að taka afstöđu til undir kaflaheitunum Að pekkja sjálfan sig og Standa skil, en í peim síðari um forgangsröðun peirra.

\section{Að pekkja sjálfan sig}

Skólastjórarnir gerđu lítinn sem engan greinarmun á mikilvægi peirra siðferđilegu gilda sem peir voru beđnir að taka afstöðu til. Stigagjöf peirra fyrir siðferđileg gildi, pað er umhyggja, jafnrétti, lýđræđi, sjálfstæđi, umburđarlyndi og réttlæti, var nánast sú sama, en rúmlega 90\% peirra gáfu peim 8-10 stig. Hugsanlegt er ađ meirihluti skólastjóranna telji 
öll pessi gildi jafnmikilvæg (yfirlýst gildi) og pví leggi peir jafnmikla áherslu á pau öll í starfi (raunveruleg gildi). Hitt er pó líklegra, að peir hafi ekki ígrundað gildi sín nægilega vel og séu pví ekki vel meðvitađir um pau og áhrif peirra á störf sín. Rannsóknir benda einmitt til pess að fæstir séu međvitađir um eigin gildi (Branson, 2005, 2007).

Í pessu samhengi hefur lengi verið lögð áhersla á að nám skólastjórnenda purfi að taka til siðferđilegra pátta ekki síđur en tæknilegra (Hodgkinson, 1991). Bjóđa purfi verđandi skólastjórnendum námskeið um stjórnun og forystu á siðferđilegum grunni. Meginmarkmið slíks náms væri að styðja starfandi jafnt sem verđandi leiðtoga í viðleitni peirra til að starfa af heilindum og proska siðferđiskennd sína (Branson, 2007; Steinunn Helga Lárusdóttir, 2014). Menntun af pessu tagi mundi ekki ađeins nýtast skólastjórnendum heldur líka nemendum sem verđa framtíđarleiđtogar pjóđarinnar. Skólar purfi pví að vera jarðvegur sem stuðli að próun siðferðilegrar breytni og siðferðilegrar dómgreindar (e. ethical behavior, ethical judgement) međal barna og unglinga ekki síđur en fullorđinna (Branson, 2007).

Í stjórnunarnámi á Menntavísindasviði hefur um langt skeið verið fjallað fræðilega um gildi og forystu á siðferđilegum grunni og nemendur hvattir til að ígrunda eigin gildi. Slík nálgun veitir pó tæplega hverjum og einum nemanda nægilegan tíma og stuđning til ígrundunar og sjálfsskođunar og til að proska siðferđilega dómgreind sína. Ein leið til úrbóta væri að nálgast viðfangefnið á sama hátt og Branson gerđi (2007) með pví að velja nemendum „mentor“ eða handleiðara sem ynni með peim yfir ákveđið tímabil að pví að ígrunda eigin gildi og velta fyrir sér hvort yfirlýst gildi og raunveruleg fari saman.

Fram hefur komið að mikilvægt sé að í skólum sé lifandi umræða um sýn og gildi allra hagsmunađila skólanna (Begley, 2004; Lumby með Coleman, 2007). Meginviðfangsefni skólastjórans í pessu samhengi er pví að skapa jarđveg međ samstarfsfólki sínu par sem viðurkennt er að mismunandi sjónarmið séu virt og hvatt til opinskárrar umræðu, bæði um opinberan gildagrunn og gildi einstaklinganna sem mynda skólasamfélagið. Forsenda pess að skólastjóranum takist petta er pó sú ađ hann pekki sjálfan sig og gildi sín og sé fær um að meta hvort yfirlýstu gildin séu sýnileg í dagsins önn.

\section{Að standa skil}

Öfugt við stigagjöf fyrir siðferđilegu gildin gerðu skólastjórarnir mikinn greinarmun á mikilvægi peirra gilda af stjórnsýslulegum toga sem peir voru beđnir að taka afstöðu til, p.e. samkeppni, skilvirkni, hagræđing, ábyrgđarskylda, afköst og árangur. Fáir skólastjórar eđa 9\% gefa t.d. samkeppni 8-10 stig. Rúmlega helmingur eđa 51\% peirra gefur par 1-4 stig og $41 \%$ gefur gildinu $5-7$ stig.

Samkeppni og samkeppnisandi getur birst á marga vegu. Í námi eru nemendur t.d. jafnan hvattir til að keppa við sjálfa sig fremur en ađra. Í ípróttum virðast gilda önnur lögmál, par er keppt innan skóla og milli skóla og nemendum sagt að stefna til sigurs. Í stærra samhengi getur samkeppni í skólastarfi birst í bví ađ ná meiri árangri en ađrir skólar á alpjóđlegum prófum, t.d. í sama sveitarfélagi eđa á landsvísu. Ef slík afstađa er fyrir hendi hjá grunnskólastjórum pá kemur hún ekki fram í pessum gögnum par sem hlutfallslega fáir skólastjórar gefa samkeppni fullt hús stiga. 
Allhátt hlutfall skólastjóra eđa 44\% gefa hagræđingu 8-10 stig og ađeins 11\% gefa henni 1-4 stig. Pegar tveir efstu flokkar stiga eru teknir saman kemur í ljós að mikill meirihluti eđa 88\% skólastjóranna gefur hagræđingu stig á bilinu 5-10. Pessar tölur benda til pess að mikill meirihluti svarenda leggi mikla áherslu á hagræđingu í störfum sínum. Líklegt er að enn gæti peirrar hagræđingarkröfu sem ríkti í skólum á árunum eftir hrun (Arney Einarsdóttir, 2010; Guđbjörg Linda Rafnsdóttir, Ásta Snorradóttir og Hjördís Sigursteinsdóttir, 2014). Sambærilegar niðurstöđur komu fram í rannsókn á áhrifum kreppunnar á skólastarf, en par voru viđmælendur í hópi kennara og foreldra fremur svartsýnir á að fjárveitingar til skólanna yrđu auknar að hruni loknu (Steinunn Helga Lárusdóttir o.fl., 2015). Pessar spár kunna að hafa gengið eftir. Áhersla skólastjóranna á hagræđingu kann pví að stafa bæđi af pví að áhrifa kreppunnar gæti enn auk pess sem ætla má að hagræđingarkrafa á opinberar stofnanir sé viðvarandi.

Hátt hlutfall skólastjóranna, eđa 91\%, gefur hins vegar gildunum árangur og ábyrgđarskylda 8-10 stig og aðeins 11\% peirra setja pessi gildi í lægsta flokk stiga, pað er 1-4 stig. Víđa reynir á ábyrgðarskyldu skólastjóra. Stigagjöf peirra fyrir pennan pátt gefur til kynna að ábyrgđarskylda sé peim ofarlega í huga og hafi mikið vægi í störfum peirra. Skólastjórar, rétt eins og aðrir sem gegna opinberum embættum, verða að standa yfirvöldum og almenningi skil á ákvörđunum sínum og athöfnum. Peir sæta margvíslegu eftirliti, bæđi međ skólastarfinu í heild, stjórnunarháttum sínum og árangri nemenda. Í Reykjavík er t.d. gerð svokölluð vinnustađakönnun árlega á afstöđu starfsmanna til margra pátta, par með stjórnunarhátta. Einnig eru dæmi um sérstakar stjórnendakannanir par sem starfsfólk gefur næsta yfirmanni sínum stig (Póranna Rósa Ólafsdóttir, 2014). Pá gerir Reykjavíkurborg úttektir á skólum á nokkurra ára fresti og Menntamálastofnum sér um að lagt sé mat á 10 grunnskóla á hverju ári (Menntamálastofnun, e.d.).

Rannsókn peirra Birnu Sigurjónsdóttur og Barkar Hansen (2014) međal skólastjóra í Reykjavík sýndi ađ áherslan á árangur nemenda var einn af premur lykilpáttum í stjórnunarháttum skólastjóra. Grunnskólunum sjálfum ber skylda til að meta árangur nemenda og nýta niðurstöđurnar til leiðsagnar um hvađ megi betur fara. Til viðbótar pessu skólamati eru lögum samkvæmt (lög um grunnskóla nr. 91/2008, 39. gr.) samræmd könnunarpróf í íslensku og stærðfræđi lögð fyrir 4. og 7. bekk grunnskóla og fyrir nemendur í 9. bekk í íslensku, stærđfræđi og ensku. Loks taka tilteknir nemendahópar pátt í alpjóđlegum könnunum eins og PISA, pað er alpjóđlegri langtímarannsókn á hæfni og getu 15 ára nemenda í lestri, náttúrufræđi og stærđfræđi (Menntamálastofnun, 2017). Pessi upptalning er ekki tæmandi en hún sýnir að opinbert eftirlit međ starfi skólanna er umtalsvert og pví ekki að undra að skólastjórar séu međvitađir um hversu mjög reynir á reikningsskil peirra gagnvart hagsmunađilum skólanna.

\section{Forgangsröoun - áhugaverðar breytingar}

Eitt af meginmarkmiðum pessarar rannsóknar var að athuga hvernig skólastjórar forgangsrađa helstu viðfangsefnum sínum og hvađa breytingar má helst greina í forgangsröđun peirra í áranna rás. Aldarfjórđungur er liđinn frá pví ađ höfundar pessarar greinar ásamt Ólafi H. Jóhannssyni gerđu fyrstu sambærilegu rannsóknina hér á landi. 
Fyrst ber að nefna að stjórnun/umsýsla er öll árin í fyrsta sæti yfir viðfangsefni sem skólastjórar verja mestum tíma í. Petta er vísbending um að enn fari mikill tími peirra í rekstur, skrifstofuhald, fjármál, bréfaskriftir, skýrslugerð o.fl. petta er í samræmi við niðurstöđur hjá Horng og félögum (2010) en pau segja að skólastjórarnir sem pau rannsökuđu hafi varið mestum tíma sínum í stjórnunarleg viðfangsefni sem snerust um „að halda skólanum gangandi“ (bls. 502). Niðurstöður Trausta Porsteinssonar og Amalíu Björnsdóttur (2016) um störf skólastjóra hér á landi ber einnig að sama brunni. Breytingar á ákjósanlegri forgangsröđun á stjórnun/umsýs/u virđast aftur á móti próast pannig að skólastjórarnir setja hana sífellt neđar í forgangsröđun eftir pví sem nær dregur í tíma.

Sýn skólastjóranna á ákjósanlegar áherslur beinist öll árin að námskrárvinnu sem peir setja ávallt í fyrsta sæti. Líta má á viðfangefnið námskrárvinnu sem kjarnaatriði í öllu skólastarfi, en pađ snýst um framkvæmd Ađalnámskrár, gerð skólanámskrár, sjálfsmat skóla, próunarverkefni og önnur störf er varđa kennsluhætti, kennsluskipulag, námsefni o.fl. Ađ námskrárvinna skipi fyrsta sæti í ákjósanlegri forgangsröđun öll árin má líta á sem vísbendingu um faglega afstöđu skólastjóranna til hlutverks síns í próun skólastarfs.

pá vekur athygli að viðfangsefnið starfsfólk, p.e. ráđningar, ráđgjöf, stuđningur, mat o.fl., rađast ofar í forgangsröđun raunverulegra viðfangsefna eftir pví sem nær dregur í tíma; er í öđru sæti síđasta áratuginn en var áđur í priðja til fimmta sæti. Breytingar á ákjósanlegri forgangsröđun virđast vera í samræmi við pessa framvindu, en skólastjórarnir setja starfsfólk einnig framar í forgangsröđun eftir pví sem nær dregur í tíma. Pessi próun kemur ekki á óvart. Í rannsókn Barkar Hansen og félaga (2008) kemur fram að með tilkomu deildarstjóra hafi hlutverk skólastjóra breyst pannig að peir hafi fengið meiri tíma til að veita starfsfólki ráđgjöf. Kenningar um skólastjórnun leggja áherslu á að stjórnendur séu framsæknir og í virku samstarfi við kennara um frampróun náms og kennslu (Harris, 2008; Hoy og Miskel, 2008; Kaplan og Owings, 2015; Louis o.fl., 2010; Robinson, 2011; Sergiovanni, 2009). Í ljósi umfjöllunar Robinsons (2011) má líta pessar breytingar á röđun viđfangsefnisins starfsfólk jákvæđum augum, en samkvæmt henni hefur forysta skólastjóra um starfspróun kennara hvađ mest áhrif á námsárangur nemenda. Annađ atriði sem ætla má að hafi valdið pví að flokkurinn starfsfólk rađast nú ofar í forgangsröð skólastjóra er pað að ófaglærðu starfsfólki hefur fjölgað mjög í grunnskólum (Hagstofa Íslands, 2018). Samsetning starfsmannahópsins hefur pví breyst og skólastjóri ber orđið ábyrgð á starfshópum sem kunna að hafa litla sem enga reynslu af skólastarfi. pessi breyting hefur án efa kallađ á aukna áherslu á viđfangsefnið starfsfólk. Petta parf pó ađ rannsaka nánar til að fá fyllri skilning á pví hvađa pættir pađ eru sem par koma við sögu.

Viđfangsefnið endurnýjun í starfi er nú í 10. og neđsta sæti og hefur ævinlega verið neđarlega í raunverulegri forgangsröð eđa i 8.-9. sæti. pað er áhyggjuefni ef lestur fræðibóka og greina, pátttaka í námskeiðum, ráđstefnum, fræđslufundum o.fl. á pví sviði skipast neđar í raunverulegum forgangi eftir pví sem nær dregur í tíma. Petta er ekki síđur áhyggjuefni í ljósi pess mikla ábyrgđarhlutverks sem skólastjórar gegna, en lög um grunnskóla (nr. 91/2008) og Ađalnámskrá grunnskóla (Mennta- og menningarmálaráđuneyti, 2012) kveđa á um að skólastjórinn skuli vera í forystu um skólastarfið, leiða pađ og móta í samræmi við nýja pekkingu og breyttar aðstæður í pjóðfélaginu hverju sinni. pað er ekki síst sjálfspekkingin sem skiptir hér máli, pekking á eigin gildum, hæfnin til að brúa bilið 
milli yfirlýstra og raunverulegra gilda og að vera meðvitaður um samspil forystu, gilda og heilinda í starfi (Begley, 2004; Branson, 2007).

Endurnýjun grunnskólastjóra í starfi er enn brýnni fyrir bá sök að allhátt hlutfall peirra hefur ekki lokið framhaldsnámi í stjórnun, einungis 38\% segjast hafa framhaldsnám á pví sviđi. pví má ætla að skólastjórar séu í mörgum tilvikum með minni formlega menntun en kennararnir sem peir eiga ađ veita forystu. Í skýrslu Ponts og félaga (2008) fyrir OECD er bent á mikilvægi pess að í stefnumörkun skólastarfs sé lögð áhersla á að efla sjálfstæđi skólastjóra og veita peim nauđsynlegan stuđning međ ráđgjöf og tækifærum til menntunar. Pessi áhersla undirstrikar að endurnýjun pekkingar eigi að vera mun ofar í forgangi en niðurstöđur pessarar rannsóknar gefa vísbendingar um. Pótt endurnýjun í starfi rađist neđarlega í raunverulegri röđun pá gildir annađ um pá ákjósanlegu pví skólastjórar setja petta viðfangefni í fjórða sæti og gerðu pað einnig árið 1991. Fylgjast parf vel með pessari próun og skapa skólastjórunum ađstæđur til að endurnýja sig markvisst í starfi. Hér bera sveitarfélög mikla ábyrgð pví peirra stuđningur við endurmenntun skólastjóra, jafnt faglegur sem fjárhagslegur, getur skipt sköpum um að skólastjórar setji hana í reynd í forgang. Sjálfir bera pó skólastjórarnir mesta ábyrgđ á eigin menntun og par skiptir metnaður peirra til að efla sig faglega með framhaldsmenntun og símenntun mestu máli.

Ekki er hægt að greina miklar breytingar á röđun annarra viðfangsefna sem könnuð voru aðrar en pær að viðfangsefnin málefni nemenda, hegðun nemenda og skólahverfið skipast örlítið neđar í raunverulegri forgangsröð eftir pví sem nær dregur í tíma. pessa tilhneigingu má túlka í ljósi pess að millistjórnendum hefur fjölgađ í tímans rás og einnig starfsfólki í stođpjónustu skóla, og má ætla að pessir starfsmenn hafi að einhverju leyti tekið við mörgum peirra viðfangsefna sem áđur voru á hendi skólastjóra. Oft er um að ræða starfsfólk með sérhæfða pekkingu, svo sem á hegđun og hegðunarvandkvæðum nemenda og tengslum heimilis og skóla. Pau viðfangsefni sem falla undir málefni nemenda beinast að samstarfi og ráđgjöf við nemendur en einnig að pjónustu við pá og nemendavernd. pessi viðfangsefni kallast pví sterkt á við pau siðferðilegu gildi sem skólastjórar segjast leggja mikla áherslu á, svo sem umhyggju, lýđræđi og jafnrétti. Í pví ljósi hefđi mátt ætla að málefni nemenda yrðu ofar í æskilegri forgangsröð en raunin varð.

Viðfangsefninu námsaðlögun var bætt við 2017 en pættir sem pví tengjast hafa mótað skólastarf mjög á síđustu árum, svo sem međ stefnumörkun um skóla án ađgreiningar og áherslu á einstaklingsmiðun í námi, fjölmenningarlega kennsluhætti, o.s.frv. (Mennta- og menningarmálaráđuneyti, 2012; Steingerđur Ólafsdóttir o.fl., 2014). Par af leiđandi er ekki hægt að greina breytingar eđa próun eins og í hinum viðfangsefnunum. Eigi að síđur vekur athygli hversu neđarlega petta viðfangsefni skipast í raunverulegri og ákjósanlegri forgangsröđum hjá skólastjórunum. Öll hugtökin í flokknum siðferđileg gildi falla ađ hugmyndafræđinni um skóla án ađgreiningar, gildi á borđ við jafnrétti, réttlæti og lýđræði sem skólastjórar segjast leggja mikla áherslu á í starfi. Í pví ljósi væri ástæđa til að ætla að viđfangsefnið námsaðlögun væri ofar í forgangsröđ skólastjóra. ÆEskilegt er að rannsaka tengsl skólastjóra við petta viðfangsefni nánar til ađ öđlast á pví betri skilning.

Í könnuninni 2017 var reynt að skođa hvort ađstæður í skólunum hefðu áhrif á forgangsröđun verkefna. Skólarnir sem um ræðir eru talsvert mismunandi að stærð og aðstæður með ýmsu móti, svo sem hvað varđar ráđandi fyrirkomulag kennslu (bekkjarkennsla, teymiskennsla, blandað skipulag), fjölda starfsmanna annarra en kennara, fjölda 
nemenda með sértæka námsörđugleika og fleira. Pessar mismunandi aðstæður virðast ekki hafa afgerandi áhrif á forgangsröđun verkefna, hvorki raunverulega né ákjósanlega, enda pótt fram hafi komið smávægilegur munur á röđun nokkurra viðfangsefna.

Einna helst virđist sem ráđandi fyrirkomulag kennslu hafi áhrif en svolítinn mun mátti greina á raunverulegri og ákjósanlegri forgangsröđun viđfangsefnanna starfsfólk, skólahverfið, námsađlögun, endurnýjun í starfi og áætlanagerđ. Í rannsókninni Starfshættir í grunnskólum (Börkur Hansen og Steinunn Helga Lárusdóttir, 2014) kom fram að stjórnunarhættir voru talsvert mismunandi eftir ríkjandi kennslufyrirkomulagi skólanna og skiluðu sér í mismikilli ánægju starfsfólks međ stjórnun og starfshætti, sem var hvađ mest í peim skólum par sem teymiskennsla var ráđandi fyrirkomulag.

Af framansögđu má pví draga pá ályktun ađ hlutverk skólastjóra í grunnskólum hafi breyst talsvert á síđastliđnum aldarfjórđungi. Ađstæđur í skólunum virðast ekki hafa afgerandi áhrif á forgangsröđun verkefna enda verkefnin sambærileg hvort sem skóli er t.d. fámennur eđa fjölmennur. Eftir sem áđur er mikilvægt ađ skapa skólastjórunum pær aðstæður að peim takist að nálgast pá kjörmynd sem hin ákjósanlega röđun endurspeglar og setur námskrárvinnu, málefni nemenda, áætlanagerđ og vinnu međ starfsfólki jafnan í efstu sætin.

\section{SAMANTEKT OG LOKAORĐ}

Á peim rúma aldarfjórđungi sem liđinn er frá fyrstu könnun höfunda árið 1991 hafa orđið talsverđar breytingar á umfangi og eđli starfs skólastjóra. Sumt má rekja til lagabreytinga, svo sem grunnskólalaga árið 1995 pegar rekstur grunnskóla var færđur til sveitarfélaga og verksvið skólastjóra varđ víđfeđmara og ábyrgð peirra jókst. Ađrar breytingar urđu í kjölfar kjarasamninga, svo sem árið 2001 pegar sett var inn ákvæđi um að skólastjóra væri heimilt að ráđa millistjórnendur. Loks hafa alpjóđlegir straumar međal annars haft pau áhrif ađ vaxandi áhersla hefur verið lögð á pátttöku í alpjóđlegum samanburđarkönnunum. Ýmsir ađrir ytri pættir hafa haft margvísleg áhrif á bæđi skólastarfið í heild og stöđu skólastjóra eins og fjallað hefur verið um í fyrri greinum höfunda. Aðstæður í skólunum virđast aftur á móti ekki hafa haft afgerandi áhrif á störf skólastjóra, ađ minnsta kosti ekki forgangsröðun viðfangsefna.

Á pessu tímabili hafa orđiđ ýmsar breytingar á bæđi æskilegri og raunverulegri forgangsröð skólastjóra. Stjórnun/umsýsla er dæmi um viðfangsefni par sem breytingar á ákjósanlegri og raunverulegri röð hafa verið fremur litlar. Petta viðfangsefni hefur ævinlega verið fremst í raunverulegri forgangsröð en í ákjósanlegri forgangsröð hefur viðfangsefnið smám saman færst aftar. Öfugt við stjórnun/umsýslu hefur námskrárvinna aldrei verið fremst í forgangsröð raunverulegra viðfangsefna en ævinlega fremst í ákjósanlegri forgangsröđ. Raunveruleg forgangsröđ námskrárvinnu hefur verið breytileg milli ára. Bilið milli ákjósanlegrar röđunar og raunverulegrar hefur einnig jafnan verið fremur lítið.

Hóflegur munur á raunmynd og kjörmynd er eđlilegur og má túlka sem metnađarfulla framtíđarsýn. Mikill munur bendir aftur á móti til pess að einhverjir pættir hamli pví að skólastjórar geri pað sem peir helst kjósa. Menntamálayfirvöld, sveitarfélög og samtök skólastjóra purfa að taka höndum saman um að greina pessa pætti og finna leiðir til pess að raunmynd og kjörmynd falli sem best saman. Skólastjórar hafa ítrekađ sagt ađ sú sé 
ekki raunin. En gildagrunnur peirra og skýr vilji til að gera viðfangsefnum sem snerta nám og kennslu hærra undir höfđi en raun ber vitni eru vísbending um að peir séu reiðubúnir til að leggja sitt af mörkum til pess og pann vilja parf að virkja.

Síđustu prjá til fjóra áratugi hafa fræđimenn lagt áherslu á ađ skólastjórar séu međvitaðir um eigin gildi, geti stađið skil á peim og haft pau að leiðarljósi í starfi. Höfundar taka undir með öđrum fræðimönnum um mikilvægi pess að skapa skólastjórunum aðstæður sem geri peim kleift að nálgast pá kjörmynd sem ákjósanleg röđun peirra endurspeglar. par skipa námskrárvinna, málefni nemenda, og vinna međ starfsfólki jafnan efstu sætin. Í pessu sambandi væri áhugavert að fylgja erlendu fordæmi og bjóđa skólastjórum handleiđslu og ráđgjöf við að spyrja gagnrýninna spurninga um eigin sýn og gildi og aðstoð við að greina hvort samræmi sé á milli orđa peirra og athafna. Ef árangur næđist gætu gildin orđið skólastjórum stuđningur og leiđarljós í daglegu starfi. pá væri með réttu hægt að halda pví fram ađ starfshættir skólastjóranna væru gildagrundađir.

\section{ATHUGASEMD}

Höfundar pakka Ólafi H. Jóhannssyni fyrir yfirlestur, góð ráð og ábendingar við gerð pessarar greinar.

\section{HEIMILDIR}

Arney Einarsdóttir. (2010). Mannaflatengdar samdráttarađgerđir: Sveigjanleiki einkafyrirtækja og opinberra stofnana í kreppu. Í Ingjaldur Hannibalsson (ritstjóri), Rannsóknir i félagsvísindum XI, Viđskiptafræđideild: Erindi flutt á ráđstefnu í október 2010 (bls. 1-10). Reykjavík: Félagsvísindastofnun Háskóla Íslands.

Bass, B. M. (1999). Two decades of research and development in transformational leadership. European Journal of Work and Organizational Psychology, 8(1), 9-32. https:// doi.org/10.1080/135943299398410

Begley, P. T. (2003). In pursuit of authentic school leadership practices. Í P. T. Begley og O. Johansson (ritstjórar), The ethical dimension of school leadership (bls. 1-12). Dordrecht: Kluwer Academic Publishers.

Begley, P. T. (2004). Understanding valuation processes: Exploring the linkage between motivation and action. International Studies in Educational Administration, 32(2), 4-17.

Begley, P. T. (2010). Leading with moral purpose: The place of ethics. Í T. Bush, L. Bell og D. Middlewood (ritstjórar), The principles of educational leadership and management (2. útgáfa, bls. 31-54). Thousand Oaks, SAGE.

Birna Sigurjónsdóttir og Börkur Hansen. (2014). Gildi og áherslur skólastjóra í grunnskólum í Reykjavík. Netla - Veftímarit um uppeldi og menntun. Sótt af http://netla. hi.is/greinar/2014/ryn/001.pdf

Branson, C. M. (2005). Exploring the concept of values-led principalship. Leading and Management, 11(1), 14-31. 
Branson, C. M. (2007). Improving leadership by nurturing moral consciousness through structured self-reflection. Journal of Educational Administration, 45(4), 471-495. https://doi.org/10.1108/09578230710762463

Branson, C. M. (2009). Leadership for an age of wisdom. Dordrecht: Springer.

Branson, C. M. og Gross, S. J. (2014). Introduction: Why ethical educational leadership? Í C. M. Branson og S. J. Gross (ritstjórar), Handbook of ethical educational leadership (bls. 1-7). New York: Routledge.

Bredeson, P. V. (2005). Building capacity in schools: Some ethical considerations for authentic leadership and learning. Values and Ethics in Educational Administration, 4(1), 1-8.

Burns, J. M. (1978). Leadership. New York: HarperCollins.

Bussey, L. H. 2006). Measuring the instructional leadership values and beliefs of school leaders. Values and Ethics in Educational Administration, 4(3),1-8.

Börkur Hansen, Ólafur H. Jóhannsson og Steinunn Helga Lárusdóttir (1994). Rannsókn á störfum skólastjóra í grunnskólum. Reykjavík: Höfundar.

Börkur Hansen, Ólafur H. Jóhannsson og Steinunn Helga Lárusdóttir. (2004). Yfirfærsla grunnskólans til sveitarfélaga: Valddreifing eđa miðstýring? Netla-Veftímarit um uppeldi og menntun. Sótt af http://netla.hi.is/greinar/2004/007/prent/index.htm

Börkur Hansen, Ólafur H. Jóhannsson og Steinunn Helga Lárusdóttir. (2008). Breytingar á hlutverki skólastjóra í grunnskólum: Kröfur, mótsagnir og togstreita. Uppeldi og menntun, 17(2), 87-104.

Börkur Hansen, Sigurlaug Hrund Svavarsdóttir, Helgi P. Svavarsson og Hanna Ragnarsdóttir (2016). Stöðugleiki í forystu menntunar nemenda af erlendum uppruna: Tilvikslýsingar úr premur grunnskólum. Netla - Veftímarit um uppeldi og menntun: Sérrit 2016 - Námsrými félagslegs réttlætis og menntunar án ađgreiningar/Learning spaces for inclusion and social justice. Sótt af http://netla.hi.is/serrit/2016/namsrymi_felagslegs_rettlaetis_og_menntunar_an_adgreiningar_learning_spaces_for_inclusion_ and_social_justice/002.pdf

Börkur Hansen og Steinunn Helga Lárusdóttir. (2014). Stjórnun og skipulag. Í Gerđur G. Óskarsdóttir (ritstjóri), Starfshættir í grunnskólum við upphaf 21. aldar (bls. 87-112). Reykjavík: Háskólaútgáfan.

Campell, C., Gold, A. og Lunt, I. (2003). Articulating leadership values in action: Conversations with school leaders. Journal of Leadership in Education, 6(3), 203-221. https:// doi.org/10.1080/1360312032000090064

Crippen, C. (2012). Enhancing authentic leadership-followership: Strengthening school relationships. Management in Education, 26(4), 192-198. https://doi. org/10.1177/0892020612439084

Duignan, P. A. (2003). Authenticity in leadership: Encouraging the heart, celebrating the spirit. National Lutheran Conference Publication: Lutheran Education Yearbook, 7. North Adelaide: Lutheran Education Australia.

Fullan, M. (2016). The new meaning of educational change (5. útgáfa). New York: Teachers College Press.

Gold, A. (2004). Values and leadership. London: University of London, Institute of Education.

Guðbjörg Linda Rafnsdóttir, Ásta Snorradóttir og Hjördís Sigursteinsdóttir. (2014). Vinnufyrirkomulag og líđan í kjölfar kreppu: Yfirlitsgrein. Íslenska pjóđfélagiđ, 5(2), 39-55. 
Gunnar E. Finnbogason. (2004). Með gildum skal land byggja: Gildagrunnur skólans. Uppeldi og menntun, 13(2),169-183.

Gunnar E. Finnbogason og Gunnar J. Gunnarsson. (2006) Trú og gildi í tilvistartúlkun unglinga: Nokkrar niðurstöđur úr rannsókn á gildismati íslenskra unglinga. Ritröđ Guðfræđistofnunar, 23, 43-69.

Hagstofa Íslands. (2018, september). Starfsfólk í grunnskólum eftir starfssviðum og kyni 1998-2017. Sótt af http://px.hagstofa.is/pxis/pxweb/is/Samfelag/Samfelag_skolamal__2_grunnskolastig__1_gsStarfsfolk/SKO02307.px/table/tableViewLayout1/ ?rxid=5d921627-36dc-455b-ade3-ac85951eb309

Hallinger, P. (2009). Leadership for 21st century schools: From instructional leadership to leadership for learning. Hong Kong: The Hong Kong Institute of Education.

Harris, A. (2008). Distributed leadership: According to the evidence. Journal of Educational Administration, 46(2), 172-188. https://doi.org/10.1108/09578230810863253

Helgi P. Svavarsson, Börkur Hansen, Samúel Lefever, Hafdís Guđjónsdóttir og Hanna Ragnarsdóttir. (2016). Leadership and diversity in Icelandic schools. Nordic Studies in Education, 35(2), 159-172. https://doi.org/10.18261/issn.1891-5949-2016-02-06

Hodgkinson, C. (1991). Educational leadership: The moral art. Albany: State University of New York Press.

Horng, E. L., Klasik, D. og Loeb, S. (2010). Principal's time use and school effectiveness. American Journal of Education, 116(4), 491-523. https://doi.org/10.1086/653625

Hoy, W. K og Miskel, C. G. (2008). Educational administration: Theory, research and practice (8. útgáfa). Boston: McGraw-Hill.

Kaplan, L.S. og Owings, W. A. (2015). Introduction to the principalship: Theory and practice. New York: Routledge.

Leithwood, K., Harris, A. og Hopkins, D. (2008). Seven strong claims about successful school leadership. School Leadership and Management, 28(1), 27-42. https://doi. org/10.1080/13632430701800060

Leithwood, K. og Mascall, B. (2008). Collective leadership effects on student achievement. Educational Administration Quarterly, 44(4), 529-561. https://doi. org/10.1177/0013161x08321221

Louis, K. S., Leithwood, K., Wahlstrom, K. L. og Anderson, S. E. (2010). Investigating the links to improved student learning: Final report of research findings. St. Paul: The University of Minnesota. Sótt af http://hdl.handle.net/11299/140885

Lumby, J. með Coleman, M. (2007). Leadership and diversity: Challenging theory and practice in education. London: SAGE.

Lög um grunnskóla, nr. 91/2008.

Matthews, L. J. og Crow, G. M. (2010). The principalship: New roles in a professional learning community. Boston: Allyn and Bacon.

McCleary, L. E. og Thomson, S. D. (1979). The senior high-school principalship: Volume III: The summary report. Reston: National Association of Secondary School Principals.

Mennta- og menningarmálaráđuneyti. (2012). Ađalnámskrá grunnskóla 2011: Almennur hluti. Reykjavík: Höfundur. Sótt af https://www.stjornarradid.is/verkefni/menntamal/ namskrar/ 
Menntamálastofnun. (e.d.). Ytra mat. Sótt af https://mms.is/ytra-mat-skola-3

Menntamálastofnun. (2017). Helstu niđurstöđur PISA 2015. Reykjavík: Höfundur. Sótt af https://mms.is/sites/mms.is/files/helstu_nidurstodur_pisa_2015_prent_-_loka.pdf

Pont, B., Nusche, D. og Moorman, H. (2008). Improving school leadership 1: Policy and practice. Paris: OECD.

Robinson, V. M. (2011). Student-centered leadership. San Francisco: Jossey-Bass.

Sergiovanni, T. J. (2009). The principalship: A reflective practice perspective (6. útgáfa). Boston: Pearson.

Sigrún Ađalbjarnardóttir. (2006). Lífsgildi. Í Úlfar Hauksson (ritstjóri), Rannsóknir í félagsvísindum VII, Félagsvísindadeild: Erindi flutt á ráđstefnu í október 2006 (bls. 779-787). Reykjavík: Félagsvísindastofnun Háskóla Íslands.

Sigurđur Kristinsson. (2014). The essence of professionalism. Í C. M. Branson og S. J. Gross (ritstjórar), Handbook of ethical educational leadership (bls. 11-23). New York: Routledge.

Steingerður Ólafsdóttir, Sigrún Sif Jóelsdóttir, Lára Rún Sigurvinsdóttir, Dóra S. Bjarnason, Anna Kristín Sigurđardóttir og Kristín Erla Harđardóttir. (2014). Skóli án ađgreiningar: Samantekt á lögum og fræđilegu efni. Reykjavík: Menntavísindastofnun Háskóla Íslands.

Steinunn Helga Lárusdóttir. (2014). Educational leadership and market values: A study of school principals in Iceland. Educational Management Administration \& Leadership, 42(4S), 83-103. https://doi.org/10.1177/1741143213510499

Steinunn Helga Lárusdóttir, Anna Kristín Sigurđardóttir, Arna H. Jónsdóttir, Börkur Hansen og Guðný Guðbjörnsdóttir. (2015). Efnahagshrunið og skólastarf í Reykjavík. NetlaVeftímarit um uppeldi og menntun. Sótt af http://netla.hi.is/greinar/2015/ryn/004.pdf

Trausti Porsteinsson og Amalía Björnsdóttir. (2016). Fagleg forysta í grunnskólum. Stjórnmál og stjórnsýs/a, 12(2), 487-510. https://doi.org/10.13177/irpa.a.2016.12.2.14

Tuana, N. (2007). Conceptualizing moral literacy. Journal of Educational Administration, 45(4), 364-378. https://doi.org/10.1108/09578230710762409

Póranna Rósa Ólafsdóttir. (2014). Reynsla skólastjóra af vinnustaðakönnunum Reykjavíkurborgar: „Pað sem skiptir mestu máli í mannlegu eđli í dag er hugrekki og seigla” (óútgefin meistararitgerð). Sótt af https://skemman.is/handle/1946/20052

Greinin barst tímaritinu 30. maí 2018 og var sampykkt til birtingar 14. september

\section{UM HÖFUNDANA}

Börkur Hansen (borkur@hi.is) er prófessor við uppeldis- og menntunarfræđideild Menntavísindasviđs Háskóla Íslands. Hann lauk B.A.-prófi í uppeldis- og sálfræđi frá Háskóla Íslands árið 1982, M.Ed.-prófi í menntastjórnun frá Háskólanum í Alberta árið 1984 og doktorsprófi frá sama skóla árið 1987. Rannsóknir hans hafa einkum beinst að skólastjórnun, skólapróun og stjórnskipulagi skóla. 
Steinunn Helga Lárusdóttir (shl@hi.is) er prófessor við uppeldis- og menntunarfræðideild Menntavísindasviđs Háskóla Íslands. Hún lauk kennaraprófi frá Kennaraháskóla Íslands árið 1975, M.Ed.-prófi i menntastjórnun frá Háskólanum í Illinois, Urbana-Champaign árið 1982 og doktorsprófi í stjórnun menntastofnana frá Lundúnaháskóla 2008. Rannsóknir hennar hafa einkum beinst að skólastjórnun, jafnrétti og kyngervi. Steinunn Helga er fyrrverandi formađur Rannsóknarstofu í menntastjórnun, nýsköpun og mati á skólastarfi.

\title{
The role and values of Icelandic compulsory school principals
}

\begin{abstract}
Contemporary theories on school leadership focus on principals' vision of their role, the values which impact their leadership behavior (Begley, 2004; Branson, 2005) and the way they prioritize their tasks. In the past quarter of a century the authors have studied the attitudes of compulsory school principals, using questionnaires; that is 1991, 2001 and 2006 (see for instance Börkur Hansen et al., 2008). This paper is a report on a study of compulsory school principals conducted in 2017. It focuses on principals' values and their actual and desirable prioritization of important tasks. Data was gathered with an electronic questionnaire sent to all Icelandic compulsory school principals; that is, 162 individuals in the spring 2017. The number of respondents was 111, making the response rate $69 \%$. The questionnaire was designed and administered by means of the Qualtrics software system and data analysis was conducted using the SPSS and EXCEL programs.

The principals were asked to assess the importance of a number of values affiliated with education by assigning points from one to ten to each of them, depending on how much emphasis they placed on them in their practice. Six of the values presented in the findings were of an ethical nature and another six management-related. Moreover, the principals were asked to rank important task areas according to the actual and desirable time devoted to each of them. The findings show that the principals do not differentiate between ethical values on the basis of their impact on their practice. Almost all the principals, or $94 \%$, say that they strongly emphasize the ethical values Care, Equality, Democracy, Autonomy, Tolerance and Justice (assign to them 8-10 points). This indicates that the principals may not have a clear picture of their own value base. It is, therefore, uncertain whether values guide them in their everyday practice as many scholars have advocated.

The principals placed a more variable emphasis on management-related values. For instance, while competition is a high priority for only $9 \%$ of the principals (gave it $8-10$ points), $44 \%$ of the principals put efficiency in the same category. Accountability and Achievement are, on the other hand, prioritized by more than $90 \%$ of the principals. The findings also show that in 2017 School Management was at the top of the ranking list of actual time allocated to a particular task area, or in the same seat as in earlier studies in
\end{abstract}


2006, 2001 and 1991. Program Development was, however, at the top of the list of desirable prioritization of tasks in 2017 as in all the earlier studies. The ranking of Personnel has changed somewhat during the time period under study; in 1991 it was in rank five of actual time devoted to this task area, in rank three in 2001 and in rank two in 2006 and 2017. The ranking of ideal time devoted to Personnel follows this pattern: in 1991 it was in rank six, in rank five in 2001, in rank two in 2006 and in rank three in 2017. Thus, the time devoted to the task area of Personnel has changed considerably during this period.

The paper sheds light on the principals' working environment, such as grades offered, number of students and teaching arrangements (regular classroom teaching, team teaching). These environmental factors were, however, not found to greatly impact principals' working practice; that is, the ranking of actual and ideal time allotted to the explored task areas. The paper finishes with a comparison with the authors' earlier research on the role of principals. It also reflects on the relevance of the findings for practice of principals as well as providing suggestions as to how principals can develop themselves professionally.

The authors set out to explore principals' values and their prioritizing of tasks. They conclude that a moderate difference between the actual and desirable prioritization of tasks is inevitable and may be an indicator of an ambitious future vision. Too much difference, however, indicates that some task areas may be preventing principals from prioritizing in accordance with their wishes. Nevertheless, the authors agree with those scholars who have recommended creating conditions which make it possible for principals to narrow the gap between the actual and the desirable. Besides, it would be of value to assist Icelandic principals in asking themselves critical questions about their vision and values and the disparity between their expressed and actual values. If successfully carried out, principals' practice can be judged as value-based.

Keywords: principals, values, order of priority, leadership

\section{ABOUT THE AUTHORS}

Borkur Hansen (borkur@hi.is) is a professor at the School of Education, University of Iceland. He finished a B.A. in education and psychology from the University of Iceland in 1982, an M.Ed. from the University of Alberta in 1984 and a Ph.D. in 1987. His major research interests are in the areas of leadership, school management, school development and educational governance.

Steinunn Helga Larusdottir (shl@hi.is) is a professor at the School of Education, University of Iceland. She finished an M.Ed. in educational administration from the University of Illinois in 1982 and a Ph.D. in educational administration from the Institute of Education, University of London, in 2008. Her research is in the areas of school leadership and management, values, gender and equality. She is a former chair of the Center for Research in Educational Leadership and Program Evaluation. 